[Regular Paper]

\title{
Oxidation of Ethane over Silicomolybdic Acid Catalysts: Catalytic Activity for Homogeneous and Heterogeneous Pathways
}

\author{
Tran Mai Huong, Ayano Suzuki, Takanori Mizushima, Hironobu OHKITA, and Noriyoshi KaKuTA* \\ Dept. of Materials Science, Toyohashi University of Technology, Tempaku-cho, Toyohashi, Aichi 441-8580, JAPAN
}

(Received August 18, 2005)

\begin{abstract}
Ethane oxidation was examined over silica supported silicomolybdic acid (SMA) catalysts under conditions described as excellent for partial oxidation to investigate the catalytic activities in the presence of non-catalytic ethane oxidation. When water vapor was absent or limited, SMA was transformed to the $\alpha-\mathrm{MoO}_{3}$ phase, $\mathrm{C}_{2} \mathrm{H}_{6}$ conversion was enhanced, and the major products were $\mathrm{C}_{2} \mathrm{H}_{4}$ and $\mathrm{CO}$, whereas little $\mathrm{HCHO}$ was formed. However, the selectivity for $\mathrm{HCHO}$ was improved by the addition of excess water vapor. The acidity of SMA, which was stabilized by water vapor as $\beta-\mathrm{MoO}_{3}$, might catalyze the scission of the $\mathrm{C}-\mathrm{C}$ bond, so partial oxidation to $\mathrm{HCHO}$ could be promoted in preference to oxidation to $\mathrm{CH}_{3} \mathrm{CHO}$. In addition, the formation of the $\mathrm{MoO}_{2}$ phase, which was observed in the co-presence of $\mathrm{C}_{2} \mathrm{H}_{6}$ and water vapor, suggested that the lattice oxygen participated in the activation and oxidation of $\mathrm{C}_{2} \mathrm{H}_{6}$.
\end{abstract}

\section{Keywords}

Ethane oxidation, Silicomolybdic acid, Molybdenum oxide catalyst, Ethylene, Aldehyde

\begin{abstract}
1. 緒言
エタンは天然ガス中の主成分であるメタン以外で最も多く含 まれる成分であるとともに, 石油精製過程で生成する軽アルカ ン類の一つである。このエタンについては燃料としての燃焼 ${ }^{1)}$ あるいは有効利用の観点から含酸素化合物やオレフィン化の研 究が行われ，酸素または $\mathrm{N}_{2} \mathrm{O}$ を用いた固体触媒による低温で のエタンの酸化的脱水素反応, 部分酸化反応に関する報告が多 数なされている2) 12)。部分酸化に関する報告では, 低温での 酸素の活性化とアルデヒド収率の向上が鍵となっている。

エタンの酸化的脱水素反応について, 最近, Lemonidou, A. A. らが昇温プログラム反応法を利用した研究を行っている ${ }^{13)}$ 。彼 らは, エタンの反応を酸素の存在下拉よび非存在下の条件で, 不均一反応（触媒反応）と均一反応（無触媒反応）を試みた。 その結果, 均一反応下のエタン酸化反応（973 K）ではエチレ ンへの選択性が高く, 気相酸化反応が脱水素反応を主としてい る反応であることを示した。そして, 均一反応で無酸素の場合, 脱水素反応が酸素存在下より低温で進行し, 酸素が低温での工 チルラジカルの生成を抑制することを示した。しかし，973 K での転化率は酸素存在下の方がはるかに高く, 高温での酸素は 逆に反応を促進する効果があるとしている。一方, 不均一反応 の場合, モリブデン触媒が存在すると低温でエタンの活性化が 起こったことから, 触媒上で酸化的脱水素によるエチレンが主 生成物として得られたとしている。高温での反応は均一反応と
\end{abstract}

* To whom correspondence should be addressed.

* E-mail: kakuta@tutms.tut.ac.jp
不均一反応の両方が起こると考えられるが, この場合でも触媒 表面酸素が反応に関与し, 無酸素下では $\mathrm{CO}$, 酸素下では $\mathrm{CO}_{2}$ の生成というように触媒なしの結果と大きく異なる結果を与 え, 格子酸素がエタン酸化反応に寄与していることを示してい た。彼らは, 含酸素化合物の生成については述べていないが, アルデヒドの生成に関しては, Zhao, Z. ら ${ }^{3), 6)} に よ る ~ C s-V / S^{2} O_{2}$ 触媒を用いたエタン酸化反応の報告がある。Cs の作用は共存 するバナジウム種の量に依存し, 低濃度ではアセトアルデヒド やアクロレインの生成を促進する。しかし，Cs を含まない触 媒ではホルムアルデヒド選択性が高く，この現象を Cs の塩基 性による酸点の中和と関連付け, Cs がない触媒では酸点によっ て C-C 結合が切断され, ホルムアルデヒド生成へ進むものと 考えている。この効果は, 低担持量で有効であり, 高担持バナ ジウムと Cs の組合せでは, 逆に酸化的脱水素活性が低下し燃 焼活性を高める効果があり, 触媒上の酸塩基特性も触媒性能を 開発する上で重要であることを指摘している。

Busca, G. ら ${ }^{14)}$, Solymosi, F. ら ${ }^{15)}$ は, バナジウム触媒上での $\mathrm{C}_{2} \mathrm{H}_{4}$ 㧍よび $\mathrm{C}_{2} \mathrm{H}_{6}$ の酸化反応について以下のように報告してい る。彼らによれば, 酸化剤としての酸素または $\mathrm{N}_{2} \mathrm{O}$ が触媒上 で分解し， $\mathrm{O}_{2}^{-}, \mathrm{O}^{-}$を形成する。それらと $\mathrm{C}_{2} \mathrm{H}_{6}$ が反応してエ チルラジカルを生じることで反応が進行し, 生じたエチルラジ カルと格子酸素が反応して触媒表面にエトキシド $\left[\mathrm{C}_{2} \mathrm{H}_{5} \mathrm{O}\right] \mathrm{s}$ を 形成すると考えている。このエトキシドについて Lunsford, J.H. ら ${ }^{16)}$ は，エトキシドが不安定なため $\beta$ - 水素引き抜きを経由す る脱水により $\left[\mathrm{C}_{2} \mathrm{H}_{4}\right] \mathrm{s}$ と $[\mathrm{OH}]_{\mathrm{s}}$ へと変化し, さらに触媒の酸 特性によって $\mathrm{C}_{2} \mathrm{H}_{4}$ が気相中に脱離すると述べている。さらに, この経路だけでなく同時に水の存在によって $\left[\mathrm{C}_{2} \mathrm{H}_{5} \mathrm{O}\right] \mathrm{s}$ との反 
応で $\mathrm{C}_{2} \mathrm{H}_{5} \mathrm{OH}$ が生成し，アセトアルデヒドへの転換が進む経路

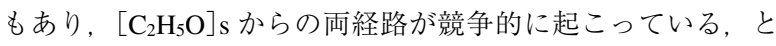
Solymosi, F. ら ${ }^{15)}$ は指摘している。また, Busca, G. ら ${ }^{14)}$ は, エ トキシドはエチレンが触媒表面のプロトンによる求電子的攻撃 でも形成し，脱水素によって $\mathrm{CH}_{3} \mathrm{CHO}$ ができる。しかし，過 度な脱水素も進行し, 生じた $\mathrm{CH}_{2}=\mathrm{CHO}$ - は不安定なため 2 重結 合が切れて $\mathrm{C} 1$ 化合物が生成すると述べている。

炭化水素の選択酸化の研究には酸化モリブデン系触媒を用い たものが多い。多くの場合，担体上に酸化モリブデンを高分散 させ，活性種の働きの効率化を図るだけでなく，他成分を添加 した複合化による機能化などが行われている。上野らは, シリ カに担持した酸化モリブデン触媒を用いて高温, 水蒸気存在下 でメタンの酸化反応を行うと, 部分酸化によるホルムアルデヒ ド生成に高い活性を示すことを報告した ${ }^{17)}$ 。彼らは，反応中に 生成するへテロポリ酸であるケイモリブデン酸（Silicomolybdic Acid: SMA）が部分酸化に寄与することを，SMAをシリカに 担持した触媒を用いた反応で確認した。

$\mathrm{SMA}$ は， $\mathrm{MoO}_{6}$ 八面体の酸素原子を 12 力所共有して $\mathrm{SiO}_{4}$ 四 面体を取り囲んだKeggin構造をしており，共有されない $\mathrm{Mo}=\mathrm{O}$ がオキソ酸素としての働きをもつ。この Keggin 構造は 水和水の作用によって結晶構造が保たれている。SMAの熱安 定温度は $573 \mathrm{~K}$ 以下であり, 熱によって結晶中の水分子が失わ れると分解して $\mathrm{MoO}_{3}$ を形成する。シリカに担持した SMAの 熱安定性については異なる議論がなされており, 高温条件下で は分解して $\mathrm{MoO}_{3}$ としての触媒作用を示すという報告がある が18), 熱安定性が向上するという報告もある。RocchiccioliDeltcheff, C. らは, IR を用いたシリカ担持 SMA 触媒の構造変

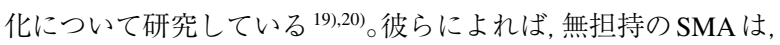
573 593 K の間で急速にKeggin 構造が分解したが，9〜 $17.6 \mathrm{wt} \% \mathrm{SMA} / \mathrm{SiO}_{2}$ 触媒では分解の開始温度は無担持の場合よ り $20 \sim 30 \mathrm{~K}$ 低くなるものの, 完全に分解するまでの温度領域 が長くなるという結果を示している。しかし, 過剩水蒸気雾囲 気に打いては $\mathrm{SMA} / \mathrm{SiO}_{2}$ の熱安定性が向上することが報告され ている。上野らは, $27 \mathrm{wt} \% \mathrm{SMA} / \mathrm{SiO}_{2}$ 触媒を水蒸気存在下で昇 温処理し, $873 \mathrm{~K}$ に扔いても反応後に SMAの構造が確認され たことを報告している ${ }^{17)}$ 。彼らは，過剩水蒸気によるSMAの 熱安定性を $\beta-\mathrm{MoO}_{3}$ との可逆反応と関連付けている。

SMAの分解について, 一定の反応条件下ではSMAは $\alpha-\mathrm{MoO}_{3}$ ではなく $\beta-\mathrm{MoO}_{3}$ に変化することが報告されてい る ${ }^{18,21)}$ 。シリカ上に形成した $\beta-\mathrm{MoO}_{3}$ は水蒸気存在下では SMA を再構築し, 選択酸化の真の活性種と考えられている21)。 $\beta-\mathrm{MoO}_{3}$ は準安定相で, その構造を調べるため様々な手法で単 相の合成が行われてきたが, 多くは $\alpha-\mathrm{MoO}_{3}$ が不純物相として 含まれている22) 24)。しかし，最近我々は，簡便な手法による $\beta-\mathrm{MoO}_{3}$ 単相の合成に成功した ${ }^{25)}$ 。

本研究では, メタン部分酸化に高活性を示した $\mathrm{SMA}$ を $\mathrm{SiO}_{2}$ に担持して, 高活性を示す $873 \mathrm{~K}$, 水蒸気雲囲気下でエ夕ン酸 化反応を行った。そして均一, 不均一反応共存下での SMAの 触媒作用, 反応中で生成する Mo 活性種の特定および触媒作用 についての考察を試みた。

\section{2. 実験}

\section{1. 触媒調製}

テトラエトキシシラン $\left[\mathrm{Si}\left(\mathrm{OC}_{2} \mathrm{H}_{5}\right)_{4}\right] 100 \mathrm{~cm}^{3}$ とプロピレン グリコール $50 \mathrm{~cm}^{3}$ の混合溶液に, 蒸留水 $175 \mathrm{~cm}^{3}$ と濃硝酸 $0.1 \mathrm{~cm}^{3}$ を加えて加水分解・重合を行った。これを $343 \mathrm{~K}$ のオイ ルバスにてゲル化するまで $3 \sim 6$ 時間擋挷し，その後 2 時間放 置した。生成したゲルをロータリーエバポレーターで減圧乾燥 し, 粉体化した。その後, $573 \mathrm{~K}$ で1時間, 続いて $923 \mathrm{~K} て ゙ 4$ 時間の焼成を行った。作製した $\mathrm{SiO}_{2}$ の比表面積は $633 \mathrm{~m}^{2} / \mathrm{g}$ で あった。

ケイモリブデン酸 $\left\{\mathrm{H}_{4}\left[\mathrm{SiMo}_{12} \mathrm{O}_{40}\right] \cdot n \mathrm{H}_{2} \mathrm{O}(n \doteqdot 30)\right.$ : 日本新 金属（株）\}を溶解した水溶液（約 $2 \% ） に$ に調製したシリカを 加え, 温浴上で擋拌しながら蒸発乾固を行った。得られた粉末 を $383 \mathrm{~K}$ で 24 時間乾燥し, $20 \mathrm{wt} \% \mathrm{SMA} / \mathrm{SiO}_{2}$ 触媒とした。

\section{2. キャラクタリゼーション}

触媒のキャラクタリゼーションには, 結晶構造を粉末 X 線 回折装置（XRD: Rigaku, RINTO 2000), SMA やその他モリブ デン種の同定についてフーリエ変換赤外分光装置（FT-IR: JASCO FTIR-410）を使用した。FT-IR の測定は, 対象とする触 媒試料と $\mathrm{KBr}$ 粉末を所定の割合で混合し，大気中にて行った。 そして，モリブデン化合物がラマン散乱に活性であり，その構 造の違いを感度良く検出することができることから, アルゴン レーザー（NEC， Model GLG2130）を装備したレーザーラマン 分光器 (JASCO, NR-1800) を使用して, 構造の変化について の測定も行った。測定は, 加熱による測定中の構造変化を避け るためレーザーパワーを最適条件に設定し, $488 \mathrm{~nm}$ の波長を 用いて $5 \mathrm{~cm}^{-1}$ の分解能で行った。

\section{3. エタン酸化反応}

反応には, 常圧固定床流通型装置（石英反応管）を使用した。 触媒 $0.6 \mathrm{~g}$ を反応管の中央に充填し, エタン (純度 $99.7 \%$ ), 酸 素 (純度 $99.5 \%$ ), 水 (蒸留水) をそれぞれの比で混合した反 応ガスを所定の温度で接触させて反応を行った。反応ガスの流 量は $50 \mathrm{~cm}^{3} / \mathrm{min} に$ 固定して行った。

蒸留水の量は脱気装置を併用した精密流量ポンプ（(株）ラ ボコーテック，LP6300）を用いて制御し，反応管の上部を $473 \mathrm{~K}$ に加温した状態で供給した。蒸留水の導入は, 触媒層の 温度が $573 \mathrm{~K}$ に達した時点で開始した。反応・生成ガス $\left(\mathrm{C}_{2} \mathrm{H}_{6}\right.$, $\mathrm{O}_{2}, \mathrm{CH}_{4}, \mathrm{C}_{2} \mathrm{H}_{4}, \mathrm{CO}, \mathrm{CO}_{2}$ ) は, Carbosieve カラム (Shimadzu, GC-8APT), 水溶性生成物 ( $\left.\mathrm{HCHO}, \mathrm{CH}_{3} \mathrm{CHO}\right)$ は, APS-201 カラム（Shimadzu, GC-8A）をそれぞれ装填したガスクロマト グラフにより定量した。エタンの転化率は, 未反応のエタン量 から算出した。

\section{3. 結果と考察}

エタンは高温下で酸素の有無にかかわらず脱水素反応により エチレンが生成することが知られている。この均一反応（無触 媒）は, 反応管の死容積をグラスウールや石英ビーズ等の粒子 で充填することで進行を抑制できる。そのため, これらの充填 材がない状況では, 均一反応と触媒による不均一反応が競争的 に起こることが予想される。本研究では, 両反応が共存してい る条件下での触媒の働きを検討した。 


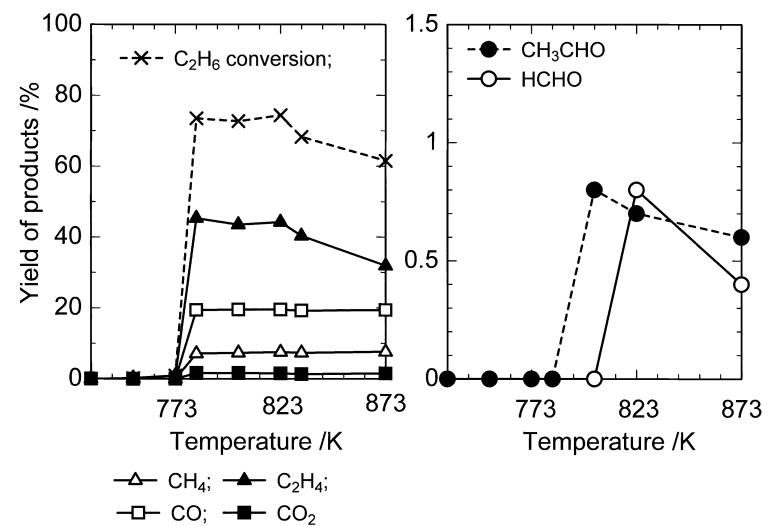

Fig. 1 Homogeneous Ethane Oxidation at Various Temperatures $\left(\mathrm{O}_{2} / \mathrm{C}_{2} \mathrm{H}_{6}=2 / 3\right.$, without water $)$

\section{1. 均一反応（無触媒）}

本反応装置における均一反応の様子を調べるため, $\mathrm{O}_{2}$ と $\mathrm{C}_{2} \mathrm{H}_{6}$ のモル比を $\mathrm{O}_{2} / \mathrm{C}_{2} \mathrm{H}_{6}=2 / 3$ に固定し, ガス流量 $50 \mathrm{~cm}^{3} / \mathrm{min}$ で反応温度を変化させ, エタン酸化反応を行った。結果を

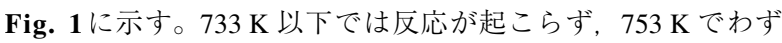
かに $\mathrm{C}_{2} \mathrm{H}_{4}$ が生成した。 $773 \mathrm{~K}$ では少量の $\mathrm{C}_{2} \mathrm{H}_{4}$ と $\mathrm{CO}$ が生成す るが， $783 \mathrm{~K}$ になると $\mathrm{C}_{2} \mathrm{H}_{6}$ の転化率が急激に上昇し約 $73 \%$ と なった。この高転化率は $823 \mathrm{~K}$ まで維持し, その時の生成物の 選択率は $\mathrm{C}_{2} \mathrm{H}_{4} 60 \%, \mathrm{CO} 26 \%, \mathrm{CH}_{4} 10 \%, \mathrm{CO}_{2} 2 \%$ であった。 これらの選択率は Lemonidou, A. A. ら ${ }^{12)}$ の $973 \mathrm{~K}$ で定常状態に 達した $\mathrm{C}_{2} \mathrm{H}_{6}$ の均一反応についての報告とほぼ一致している。 また,アルデヒドについては, $803 \mathrm{~K} て ゙ は \mathrm{CH}_{3} \mathrm{CHO}$ のみ生成 したが, $823 \mathrm{~K} て ゙ は \mathrm{HCHO}$ も生成し, 反応温度が高温になる と両アルデヒドの収率はやや低下した。均一反応は923〜 $973 \mathrm{~K}$ で高転化率になると言われているが, 本条件では比較的 低温で高転化率となり, 温度上昇とともに減少する傾向にあっ た。

\section{2. エタン酸化反応 $(873 \mathrm{~K})$ における $\mathrm{O}_{2} / \mathrm{C}_{2} \mathrm{H}_{6}$ 比の影響}

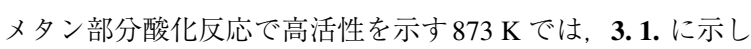
たように $\mathrm{C}_{2} \mathrm{H}_{6}$ 転化率 $60 \%$ の均一反応が起こっていることが分 かった。そこで，この反応温度に扔ける SMA 触媒の作用を検 討するため, $20 \mathrm{wt} \% \mathrm{SMA} / \mathrm{SiO}_{2}$ 触媒を用いて $\mathrm{O}_{2} / \mathrm{C}_{2} \mathrm{H}_{6}$ 比の及ほ す影響について検討した。反応は，水蒸気を導入しない条件で 混合ガス $\left(50 \mathrm{~cm}^{3} / \mathrm{min}\right)$ 中の $\mathrm{O}_{2} / \mathrm{C}_{2} \mathrm{H}_{6}$ 比を変え $\left\{\mathrm{O}_{2} / \mathrm{C}_{2} \mathrm{H}_{6}: 1 / 3=0.3\right.$, $1 / 2=0.5$ (均一のみ) $, 2 / 3=0.6,4 / 5=0.8\}$, 反応温度 $873 \mathrm{~K}$ で行っ た。

\subsection{1. 均一反応}

エタン酸化反応に対する反応ガス中の $\mathrm{O}_{2}$ 濃度の影響を調べ るため, $873 \mathrm{~K}$ で空の石英反応管を用いて行った。2 時間行っ た結果を Fig. 2 に示す。 $\mathrm{O}_{2}$ 濃度の増加に伴い $\mathrm{C}_{2} \mathrm{H}_{6}$ 転化率は増 加した。反応ガス中の $\mathrm{O}_{2} / \mathrm{C}_{2} \mathrm{H}_{6}$ 比が 0.5 までは直線的に増加し 転化率 $60 \%$ となったが，それ以降は緩やかな増加を示した。 $\mathrm{CO}, \mathrm{CH}_{4}$ と $\mathrm{CO}_{2}$ の収率は $\mathrm{O}_{2}$ 濃度の増加とともに増加するのに 対し, $\mathrm{C}_{2} \mathrm{H}_{4}$ の収率は $\mathrm{O}_{2} / \mathrm{C}_{2} \mathrm{H}_{6}$ 比が 0.5 で最大となると減少した。 アルデヒドについては, どの $\mathrm{O}_{2}$ 濃度に打いても $\mathrm{CH}_{3} \mathrm{CHO}$ と HCHOはほぼ一定収率であった。これらを選択性から調べると，
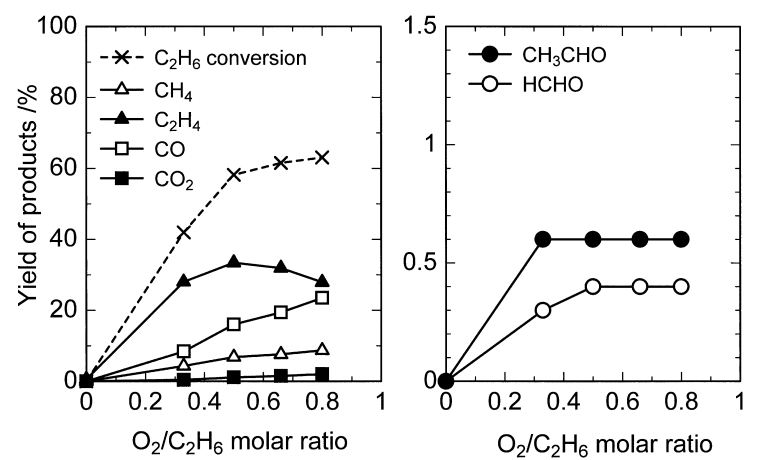

Fig. 2 Effect of $\mathrm{O}_{2} / \mathrm{C}_{2} \mathrm{H}_{6}$ Molar Ratios on Homogeneous Ethane Oxidation at $873 \mathrm{~K}$ without Water
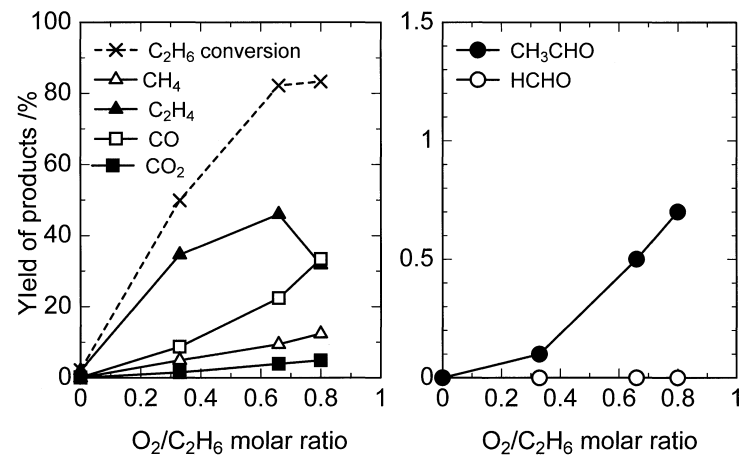

Fig. 3 Product Yields over $20 \mathrm{wt} \% \mathrm{SMA} / \mathrm{SiO}_{2}$ Catalyst at Various $\mathrm{O}_{2} / \mathrm{C}_{2} \mathrm{H}_{6}$ Molar Ratios under Homogeneous Ethane Oxidation at $873 \mathrm{~K}$ without Water

$\mathrm{CO}, \mathrm{CH}_{4}$ と $\mathrm{CO}_{2}$ は $\mathrm{O}_{2}$ 濃度の増加とともに直線的に増加するの に対し $\mathrm{C}_{2} \mathrm{H}_{4}$ は直線的に減少した。アルデヒドには大きな変化 はみられなかった。

\section{2. 2. $20 \mathrm{wt} \% \mathrm{SMA} / \mathrm{SiO}_{2}$ 触媒}

同様な条件で $0.6 \mathrm{~g}$ の触媒を反応管の中央に充填して, エ夕 ン酸化反応に打ける $\mathrm{O}_{2}$ 濃度の影響を検討した。結果を Fig. 3 に示す。

無酸素下では，主に $\mathrm{C}_{2} \mathrm{H}_{4}$ とわずかな $\mathrm{CO}$ が生成し，刺激臭 を持つ生成物と反応管下部への黄褐色の固形物の付着が認めら れた。この現象は均一反応では観測されず， $\mathrm{C}_{2} \mathrm{H}_{6}$ が触媒上で 活性化され, 脱水素反応により生成した物質が重合したものと 推察される。 $\mathrm{O}_{2}$ が共存すると, $\mathrm{O}_{2} / \mathrm{C}_{2} \mathrm{H}_{6}$ 比が $0.6(2 / 3)$ になる まで $\mathrm{C}_{2} \mathrm{H}_{6}$ 転化率は直線的に増加して約 $80 \%$ を超え, 反応に触 媒が関与していることがわかる。生成物では, $\mathrm{C}_{2} \mathrm{H}_{4}$ が $\mathrm{O}_{2}$ 濃度 の上昇とともに均一反応を上回る収率を示したが, $\mathrm{CO}, \mathrm{CH}_{4}$ と $\mathrm{CO}_{2}$ は酸素濃度の変化に対し均一反応と同様な挙動を示し た。一方, $\mathrm{CH}_{3} \mathrm{CHO}$ は $\mathrm{O}_{2}$ 濃度の増加に伴って収率は増加する が均一反応に比べて低下し, HCHO の生成はほとんど検出さ れなかった。このことから, 均一反応からのエタン転化率の増 加部分がエチレン生成に進み, 触媒存在下では脱水素反応が主 に進行していることを示していた。また, 同時に触媒の存在で アルデヒド, 特にホルムアルデヒドの生成が抑制され, この条 件では部分酸化反応が進行しにくいことを示している。 


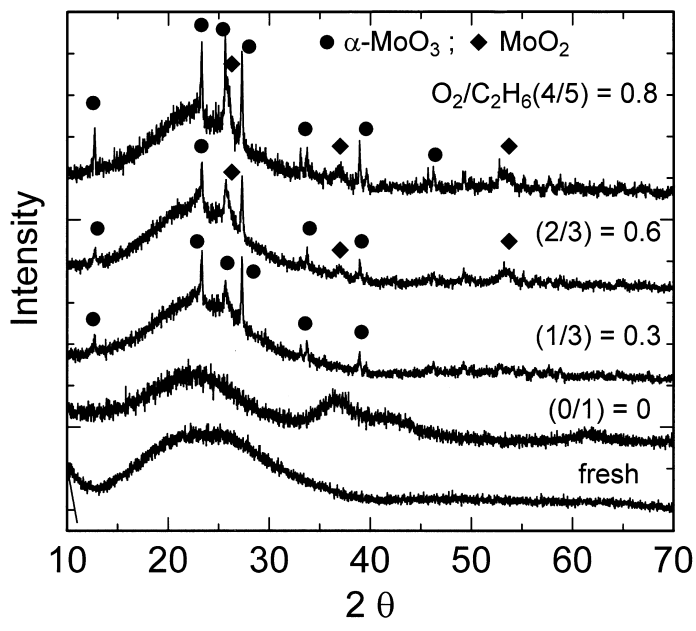

Fig. 4 X-Ray Diffraction Patterns of the $20 \mathrm{wt} \% \mathrm{SMA} / \mathrm{SiO}_{2}$ Catalyst after Reaction at Different $\mathrm{O}_{2} / \mathrm{C}_{2} \mathrm{H}_{6}$ Molar Ratios

\section{2.3. キャラクタリゼーションと触媒作用}

反応後の触媒のXRDによる構造変化を観察した結果を Fig. 4 に示す。無酸素条件下ではシリカゲルのブロードなピー クのほかに $35^{\circ}$ 付近に回折ピークが見られたが, モリブデン種 を同定することができなかった。これは, SMAの分解により 生成した Mo 酸化物の格子酸素が反応に使用され, 種々の還元 型 $\mathrm{MoO}_{x}$ が生成しているためではないかと考えられる。また, 反応後の触媒は黒く変色しており, 反応中に多量の炭素が析出 しており，3.2.2. で観測された重合の存在を支持している。そ して, $\mathrm{O}_{2}$ が存在すると $\alpha-\mathrm{MoO}_{3}$ の回折ピークが出現し, SMA が分解していることを示していた。また， $\mathrm{O}_{2}$ 濃度が増加する に伴い $\alpha-\mathrm{MoO}_{3}$ のピークとともに $\mathrm{MoO}_{2}$ に帰属する回折ピーク も出現した。

反応後の触媒の FT-IR スペクトルを測定したところ，全ての 反応条件下で SMA に帰属するピークが消失し，XRDの結果と 同様にSMA が分解していることを示していた。

以上の反応後の触媒物性と均一・不均一反応結果から, 無酸 素条件下では, 触媒表面で $\mathrm{C}_{2} \mathrm{H}_{6}$ の水素の引き抜きによる脱水 素反応が優位であること，CO が生成したことから，SMAが 分解して生成した Mo 酸化物の格子酸素が反応に関与して酸化 的脱水素抢よびその後の酸化反応が起こり, $\mathrm{MoO}_{x}$ を生成する。 一方, 気相 $\mathrm{O}_{2}$ が存在すると, $\mathrm{MoO}_{x}$ は消失し, $\alpha-\mathrm{MoO}_{3}$ と $\mathrm{MoO}_{2}$ 相が生成する。そして, $\mathrm{C}_{2} \mathrm{H}_{4}$ の生成も増加する。均一。 不均一共存反応下での $\mathrm{C}_{2} \mathrm{H}_{4}$ の平均生成速度が約 $30 \mathrm{mmol} / \mathrm{h}$ で あるのに対し， $\mathrm{H}_{2}$ の生成速度はその約 $1 / 100$ 程度であったこと から， $\alpha-\mathrm{MoO}_{3}$ 上で $\mathrm{C}_{2} \mathrm{H}_{6}$ の酸化的脱水素が進行し, $\mathrm{MoO}_{2}$ が生 成すると同時に $\mathrm{H}_{2} \mathrm{O}$ の生成も起こっていることを示している。 さらに, $\mathrm{O}_{2}$ 濃度が高くなると $\mathrm{C}_{2} \mathrm{H}_{6}$ の転化率が向上し, 各生成 物の収率も向上する。特に, $\mathrm{O}_{2}$ 濃度が高い条件下での $\mathrm{CO}$ 収 率の向上が大きい。アルデヒドについては, $\alpha-\mathrm{MoO}_{3} や \mathrm{MoO}_{2}$ が生成するとホルムアルデヒドは生成しないことがわかった。 同様に，アセトアルデヒド生成も触媒が存在するとその収率が 低下する。このことは, 均一反応で生成したアルデヒド類が $\alpha-\mathrm{MoO}_{3}$ により酸化されている可能性がある。 $\mathrm{CO}$ 収率の向上
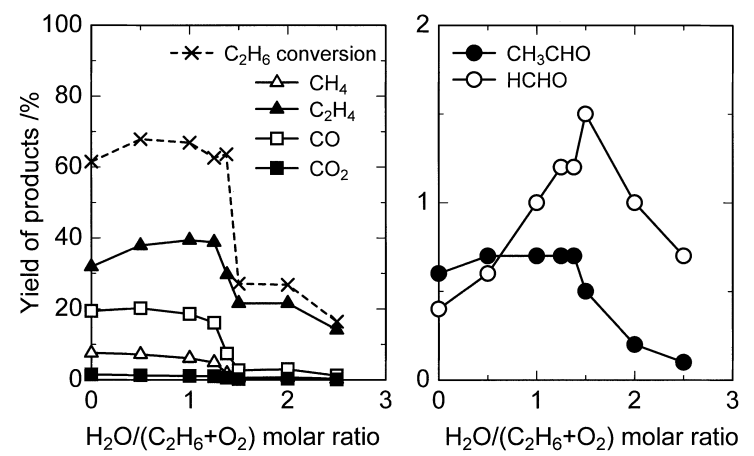

Fig. 5 Effect of $\mathrm{H}_{2} \mathrm{O} /\left(\mathrm{C}_{2} \mathrm{H}_{6}+\mathrm{O}_{2}\right)$ Molar Ratios on Homogeneous Ethane Oxidation at $873 \mathrm{~K}\left(\mathrm{O}_{2} / \mathrm{C}_{2} \mathrm{H}_{6}=2 / 3\right)$

は均一反応で生成したアルデヒド類の酸化を示しているのでは ないかと考えられる。しかし， $\mathrm{O}_{2}$ 濃度が高くなるとアセトア ルデヒドの収率が増加するのは, 気相酸素の増加により触媒上 で活性化される酸素量が増しエタンの選択酸化反応が向上した と推定している。ホルムアルデヒドはアセトアルデヒドの酸化 からも生成することから (), 反応に寄与するアセトアルデヒド あるいはホルムアルデヒドが $\alpha-\mathrm{MoO}_{3}$ により主に $\mathrm{CO}$ まで酸化 されたと考えられる。

\section{3. エタン酸化反応（873 K）における水蒸気の影響}

エタンの酸化反応では, 水蒸気下で行った報告例は少ない。 しかし, 水蒸気の添加効果としてエタンの転化率は低下するが アルデヒドへの選択性が向上することが報告されている26,27)。 また, ヘテロポリ酸は水蒸気の存在下でその構造を維持するこ

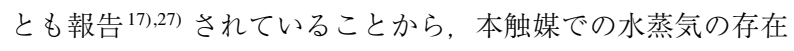
は重要であると考えられる。

\subsection{1. 均一反応}

3.2.の結果から一番活性が高い結果となった $\mathrm{O}_{2} / \mathrm{C}_{2} \mathrm{H}_{6}$ 比を $2 / 3$ とし, 反応ガス $\left(50 \mathrm{~cm}^{3} / \mathrm{min}\right)$ に対する水蒸気のモル比 $\left\{\mathrm{H}_{2} \mathrm{O} /\right.$ $\left.\left(\mathrm{C}_{2} \mathrm{H}_{6}+\mathrm{O}_{2}\right)\right\}$ を変化させて, $873 \mathrm{~K}$ でエタン酸化反応を行った。 結果を Fig. 5 に示す。

$\mathrm{H}_{2} \mathrm{O} /\left(\mathrm{C}_{2} \mathrm{H}_{6}+\mathrm{O}_{2}\right)$ の比が 1.25 までは $\mathrm{C}_{2} \mathrm{H}_{6}$ 転化率㧍よび生成 物の収率には, 水蒸気の影響が見られなかった。水蒸気量を増 加して 1.38 にすると気体生成物の収率が減少し, 1.5 以上にな ると転化率は $27 \%$ 以下まで減少し, $\mathrm{CH}_{4}, \mathrm{CO}_{2}$ は $1 \%$ 以下, $\mathrm{CO}$ は $3 \%$ 程度の収率となった。このとき $\mathrm{C}_{2} \mathrm{H}_{4}$ は $20 \%$ と最も 多く生成した。 $\mathrm{CH}_{3} \mathrm{CHO}$ は $\mathrm{H}_{2} \mathrm{O} /\left(\mathrm{C}_{2} \mathrm{H}_{6}+\mathrm{O}_{2}\right)$ の比が 1.5 以上で 減少し, $\mathrm{C}_{2} \mathrm{H}_{6}$ の転化率と同じ挙動を示した。これに対し, $\mathrm{HCHO}$ では, $\mathrm{H}_{2} \mathrm{O} /\left(\mathrm{C}_{2} \mathrm{H}_{6}+\mathrm{O}_{2}\right)$ の比が 0 から 1.38 の間, 水蒸気 の増加に伴い収率が増加したが, 1.5 以上になると $\mathrm{CH}_{3} \mathrm{CHO}$ と 同様に減少した。

\section{3. 2. $20 \mathrm{wt} \% \mathrm{SMA} / \mathrm{SiO}_{2}$ 触媒}

$20 \mathrm{wt} \% \mathrm{SMA} / \mathrm{SiO}_{2}$ 存在下で $\mathrm{O}_{2}$ と $\mathrm{C}_{2} \mathrm{H}_{6}$ のモル比を $2 / 3$ に固定 し, 水蒸気の添加量を変化させ $\mathrm{C}_{2} \mathrm{H}_{6}$ 酸化反応に対する水蒸気 の影響について調べた結果を Fig. 6に示す。

触媒を使用した反応では, $\mathrm{H}_{2} \mathrm{O} /\left(\mathrm{C}_{2} \mathrm{H}_{6}+\mathrm{O}_{2}\right)$ の比が1までは 転化率 $80 \%$ 程度を維持し, 均一反応の場合より高いという Fig. 2で示す結果と同じであった。しかし, 均一反応では高転 化率であった 1.25 から $\mathrm{C}_{2} \mathrm{H}_{6}$ 転化率が減少し，1.5になると転化 


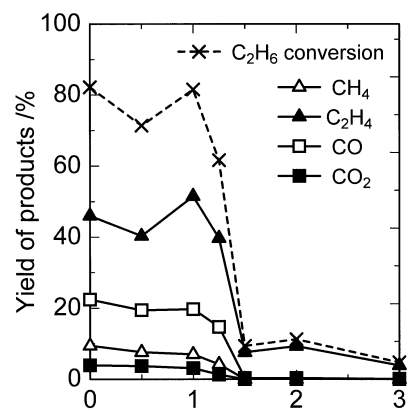

$\mathrm{H}_{2} \mathrm{O} /\left(\mathrm{C}_{2} \mathrm{H}_{6}+\mathrm{O}_{2}\right)$ molar ratio

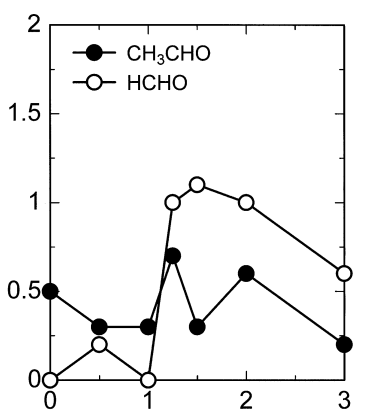

$\mathrm{H}_{2} \mathrm{O} /\left(\mathrm{C}_{2} \mathrm{H}_{6}+\mathrm{O}_{2}\right)$ molar ratio
Fig. 6 Product Yields over $20 \mathrm{wt} \% \mathrm{SMA} / \mathrm{SiO}_{2}$ Catalyst at Various $\mathrm{H}_{2} \mathrm{O} /\left(\mathrm{C}_{2} \mathrm{H}_{6}+\mathrm{O}_{2}\right)$ Molar Ratios under Homogeneous Ethane Oxidation at $873 \mathrm{~K}$

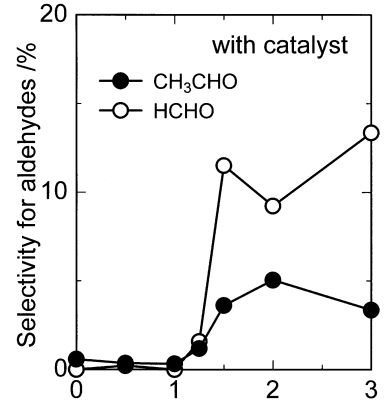

$\mathrm{H}_{2} \mathrm{O} /\left(\mathrm{C}_{2} \mathrm{H}_{6}+\mathrm{O}_{2}\right)$ molar ratio

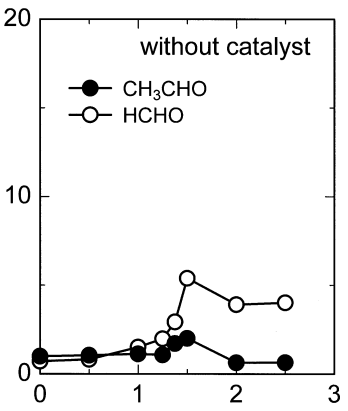

$\mathrm{H}_{2} \mathrm{O} /\left(\mathrm{C}_{2} \mathrm{H}_{6}+\mathrm{O}_{2}\right)$ molar ratio
Fig. 7 Selectivities for $\mathrm{CH}_{3} \mathrm{CHO}$ and $\mathrm{HCHO}$ in Ethane Oxidation at $873 \mathrm{~K}$ with and without the $20 \mathrm{wt} \% \mathrm{SMA} / \mathrm{SiO}_{2}$ Catalyst

率は均一反応より低い $10 \%$ 程度となった。このとき, $\mathrm{CH}_{4}$, $\mathrm{CO}_{2}$ はほとんど生成せず, $\mathrm{C}_{2} \mathrm{H}_{4}$ の収率も $10 \%$ 以下となった。 一方, アルデヒドの収率については, 均一反応と大きな違いが 見られなかった。

そこで，均一・不均一反応における選択性について検討した。 水蒸気添加による選択率への影響は, アルデヒド選択率で大き な違いが見られた以外両反応に顕著な差はなかった。アルデヒ ドの選択率の結果を Fig. 7 に示す。不均一反応に扔いて, $\mathrm{H}_{2} \mathrm{O} /$ $\left(\mathrm{C}_{2} \mathrm{H}_{6}+\mathrm{O}_{2}\right)$ の比が 1.5 以上になると $\mathrm{CH}_{3} \mathrm{CHO}$ は $5 \%$ 近くまで 上昇し, HCHOについては $10 \%$ 以上の選択率を示した。均一 反応でも同様な傾向が見られたがその選択率は不均一反応の半 分程度であった。このことから，モル比 $1.5\left(\mathrm{C}_{2} \mathrm{H}_{6} / \mathrm{O}_{2} / \mathrm{H}_{2} \mathrm{O}=\right.$ 3/2/7.5) では, エ夕ン酸化反応に打ける酸化的脱水素反応が抑 制され，触媒による部分酸化反応が促進されることがわかった。

\subsection{3. キャラクタリゼーションと触媒作用}

水蒸気のモル比を変化させた反応後の触媒の XRD 結果を Fig. 8 に示す。水蒸気と反応ガスの比が 1.0 以下の反応後の触 媒には, SMA が分解し $\alpha-\mathrm{MoO}_{3}$ が生成していることがわかる。 しかし, 水蒸気 /ガス比が 1.5 以上になると $\alpha-\mathrm{MoO}_{3}$ の回折ピー クが消失し, $\beta-\mathrm{MoO}_{3}$ の回折ピークと, $\mathrm{MoO}_{2}$ に帰属する小さな ピークも出現した。水蒸気を導入しない結果と比較すると, $\alpha-\mathrm{MoO}_{3}$ が存在するときはエチレン等の生成が進み， $\alpha$ 相がな くなり $\beta$ 相が生成するとアルデヒド生成が有効になることを

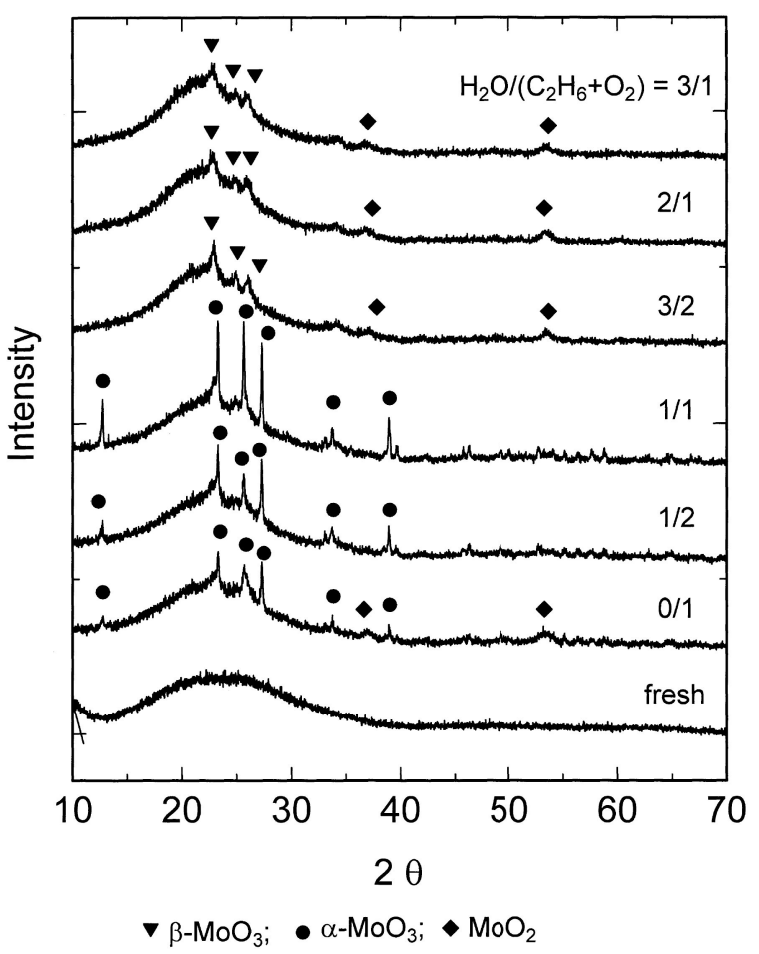

Fig. 8 X-Ray Diffraction Patterns of the $20 \mathrm{wt} \% \mathrm{SMA} / \mathrm{SiO}_{2}$ Catalyst after Reaction at Different $\mathrm{H}_{2} \mathrm{O} /\left(\mathrm{C}_{2} \mathrm{H}_{6}+\mathrm{O}_{2}\right)$ Molar Ratios

示唆している。一方, 反応後の FT-IR 測定では, SMAに由来 する吸収が消失し分解していることを示していたが, Mo 種に 由来する吸収の確認は困難であった。ただし, 水蒸気 /ガス比 が 1.5 以上で $969 \mathrm{~cm}^{-1}$ 付近に小さな吸収が出現し, SMAの末端 $\mathrm{Mo}=\mathrm{O}$ による吸収に近いことから SMAに近い構造が維持され ていると推定された。そこで, ラマンスペクトルを測定して Mo 種の確認を行った。結果を Fig. 9に示す。水蒸気/ガス比

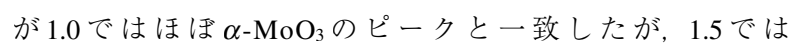
$\beta-\mathrm{MoO}_{3}$ に帰属するピーク 22,25) と $965 \mathrm{~cm}^{-1}$ 付近に FT-IR で観測 されたSMA に由来すると思われるピークが見られ，水蒸気の 量が多くなると $\beta-\mathrm{MoO}_{3}$ と $\mathrm{SMA}$ が共存していることが示唆さ れた。これは, シリカ上で担体側がSMAで, それ以外が $\beta-\mathrm{MoO}_{3}$ 構造を有している $\mathrm{Mo}$ 種が生成しているのではないか と考えている。これらの挙動は, 報告された水蒸気の存在下で のヘテロポリ酸の挙動 ${ }^{17), 27)}$ と一致しており, 水蒸気の添加が ヘテロポリ構造の安定化に寄与していることがわかる。

これらの結晶相の形成に扔ける水蒸気の役割を検討した。酸 素のみで触媒を 823 から $873 \mathrm{~K}$ まで温度を変化させて加熱した ところ, $823 \mathrm{~K}$ から $\alpha-\mathrm{MoO}_{3}$ が生成し, $873 \mathrm{~K}$ では $\alpha-\mathrm{MoO}_{3}$ と少 量の $\beta-\mathrm{MoO}_{3}$ 相の存在が XRD およびラマン測定より判明した。 そこで, 酸素に対し, 過剩な水蒸気を添加して $873 \mathrm{~K}$ で加熱処 理をすると, 大部分が $\beta-\mathrm{MoO}_{3}$ 相を形成し, 少量の $\alpha-\mathrm{MoO}_{3}$ 相 ができていることがわかった。続いて, 過剩な水蒸気とエタン のみで $873 \mathrm{~K} て ゙ 反$ 応を行ったところ，ほとんどが $\mathrm{MoO}_{2}$ 相のみ であった。このことから， $\alpha-\mathrm{MoO}_{3}$ 相と $\beta-\mathrm{MoO}_{3}$ 相は酸素ある いは水蒸気との共存下で形成するが, $\mathrm{MoO}_{2}$ 相はエタンと水蒸 気が共存した時に生成することから, エタンの酸化的脱水素で 


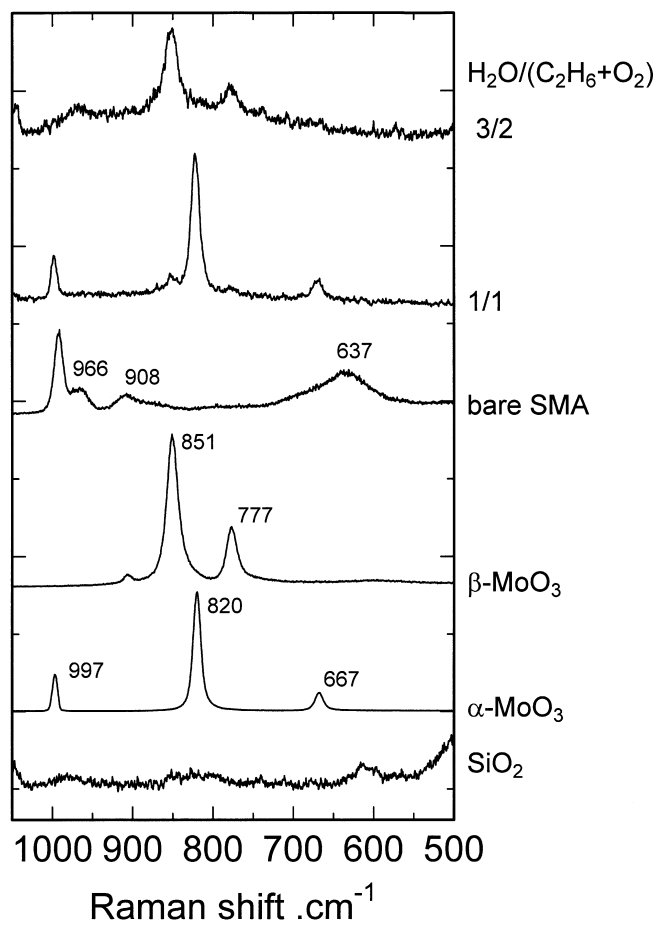

$\alpha-\mathrm{MoO}_{3}$ and silicomolybdic acid (SMA) were commercial products; $\beta-\mathrm{MoO}_{3}$ was synthesized ${ }^{24)}$.

Fig. 9 Raman Spectra of the $20 \mathrm{wt} \% \mathrm{SMA} / \mathrm{SiO}_{2}$ Catalyst after Reaction at Different $\mathrm{H}_{2} \mathrm{O} /\left(\mathrm{C}_{2} \mathrm{H}_{6}+\mathrm{O}_{2}\right)$ Molar Ratios

生成した $\mathrm{MoO}_{2}$ 相を水蒸気が安定化させているのではないかと 考えた。つまり, 水蒸気を添加せずに酸素量が増加すると $\mathrm{MoO}_{2}$ 相が生成した (Fig. 4) のは, 反応中に生成した水蒸気 (参 照 3. 2.3.）が $\mathrm{MoO}_{2}$ 相の迅速な酸化を抑制したためではないか と推定している。

反応の結果と併せて検討すると, 触媒存在下では, 水蒸気と 反応ガス比が 1.0 までは水蒸気量が増加しても均一反応よりも 高い $\mathrm{C}_{2} \mathrm{H}_{6}$ 活性化が維持され，その場合， $\mathrm{C}_{2} \mathrm{H}_{4}, \mathrm{CO}_{2}$ の生成が 促進される。生成する水素の量も, 水蒸気を添加しない時 (3.2.3. 参照) と同様な結果を示し, 水蒸気の影響が少ないこ とを示している。つまり, $\mathrm{SMA} \alpha \alpha-\mathrm{MoO}_{3}$ へと分解し, この $\alpha-\mathrm{MoO}_{3}$ が均一反応共存下で $\mathrm{C}_{2} \mathrm{H}_{6}$ の酸化脱水素反応を促進し て, $\mathrm{C}_{2} \mathrm{H}_{6}$ の転化率と $\mathrm{C}_{2} \mathrm{H}_{4}$ の収率を向上させている。そして, $\mathrm{HCHO}$ の生成が見られず, $\mathrm{CH}_{3} \mathrm{CHO}$ の収率も低い。このこと から, 触媒表面に生成した $\alpha-\mathrm{MoO}_{3}$ 上では均一反応で生成した $\mathrm{HCHO}$ や $\mathrm{CH}_{3} \mathrm{CHO}$ の酸化反応が進行しているのではないかと 推定される。

過剩な水蒸気が存在すると, 触媒上には $\beta-\mathrm{MoO}_{3}$ と $\mathrm{SMA} の$ $\mathrm{Mo}=\mathrm{O}$ の一部が残存していた。このとき, $\mathrm{CO}, \mathrm{CO}_{2}, \mathrm{CH}_{4}$ はほ とんど生成せず, $\mathrm{CH}_{3} \mathrm{CHO}$ の生成量との相関なしに $\mathrm{HCHO}$ の 選択性が急増した。Zhao, Z. ら 6 は, 触媒上の固体酸が $\mathrm{C}_{2} \mathrm{H}_{6}$ の $\mathrm{C}-\mathrm{C}$ 結合の切断に有効であり，固体酸性を弱めることで $\mathrm{CH}_{3} \mathrm{CHO}$ の選択性が増加することを報告している。このこと から, 過剩な水蒸気が存在していることによって保持されてい る SMA が $\mathrm{C}-\mathrm{C}$ 結合の切断に寄与して $\mathrm{CH}_{3}$ ・を生成し, その後
の部分酸化によって HCHO が生成するため選択率が向上した ものと説明できる。 $\beta-\mathrm{MoO}_{3}$ と $\mathrm{SMA}$ が水蒸気の存在下で可逆 的に構造変化をすることも $\mathrm{C}-\mathrm{C}$ 結合の切断の促進に寄与して いると思われる。現在のところ $\mathrm{MoO}_{2}$ 相の反応中での役割は不 明であるが, $\mathrm{MoO}_{2}$ 相はエタンの脱水素過程で生成し, 同時に 生成した水蒸気が気相酸素による迅速な酸化を抑制したため酸 化䨌囲気にもかかわらず検出されたものと推定している。この ことから， $\mathrm{O}_{2} / \mathrm{C}_{2} \mathrm{H}_{6}$ 下での反応ではエタンの活性化が $\alpha-\mathrm{MoO}_{3}$ の格子酸素が関与して進み, その結果として $\mathrm{MoO}_{2}$ 相が生成す ると説明することができる。しかし, 過剩な水蒸気の存在にお ける $\mathrm{MoO}_{2}$ 相の由来や $\mathrm{MoO}_{2}$ 相形成に伴う反応生成物（エタン, エトキシド等）とアルデヒド生成との関連も不明であるため, 検出されたモリブデン種 $\left(\mathrm{SMA}, \beta-\mathrm{MoO}_{3}, \mathrm{MoO}_{2}, \alpha-\mathrm{MoO}_{3}\right)$ の反応活性を詳しく調べる必要がある。ちなみに, Banares, A. M. ${ }^{26)}$ は, 水蒸気の存在が $\mathrm{MoO}_{x} / \mathrm{SiO}_{2}$ 触媒での $\mathrm{CH}_{3} \mathrm{CHO}$ 選択性 を向上させると報告している。本結果では, HCHOの選択性 の向上が顕著である。この違いは, 水蒸気の存在下で生成した Mo 種と SMA の固体酸性の違いが選択性に表れたものであり, エタン酸化反応では Mo 種の固体酸性がホルムアルデヒドの生 成に重要であると考えている。また，Fig. 6から過剩な水蒸気 の添加ではメタン生成が見られない。均一反応ではメタン生成

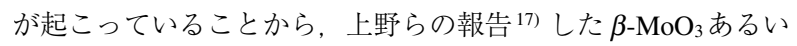
はSMAによるメタンの部分酸化反応も進行し, ホルムアルデ ヒド選択性向上に寄与しているかもしれない。

水蒸気存在下での反応では, 担持したSMAの一部が分解し て反応管下部に針状の $\alpha-\mathrm{MoO}_{3}$ として析出して活性の低下が起 こる。しかし, $20 \mathrm{wt} \% \mathrm{SMA} / \mathrm{SiO}_{2}$ 触媒は過剩水蒸気下で 10 時 間反応を行っても活性が安定し，アルデヒドの中ではホルムア ルデヒドが高い収率（約 $1.5 \%$ ）を維持していたことから, 本 触媒では活性種がシリカ担体上に比較的安定に固定化されてい るといえる。

\section{4. 結 論}

シリカに担持したSMA 触媒を用いて, メタン部分酸化反応 に高活性な条件下でエ夕ン酸化反応を行った。特に, 無触媒反 応が起こる均一反応と共存する条件で触媒反応を行い, 水蒸気 の存在による触媒の作用について以下の知見を得た。

（1）SMA は, 反応中に水蒸気が存在しない場合や水蒸気量が 少ない場合（水と反応ガスのモル比 1.5 以下）では, 酸素によ り $\alpha-\mathrm{MoO}_{3}$ へと分解した。触媒表面に $\alpha-\mathrm{MoO}_{3}$ が存在すると, $\mathrm{C}_{2} \mathrm{H}_{6}$ 転化率は向上するが $\mathrm{C}_{2} \mathrm{H}_{4}$ と $\mathrm{CO}$ が主生成物となり, HCHO はほとんど生成しない。

（2）過剩な水蒸気の存在下で, $\mathrm{SMA}$ は $\beta-\mathrm{MoO}_{3}$ と $\mathrm{SMA}$ 構造を 保持する。水蒸気は $\mathrm{SiO}_{2}$ 上の $\mathrm{SMA}$ の分解速度を低下させ, 高 温での酸素雲囲気においても $\alpha-\mathrm{MoO}_{3}$ への分解を抑制する。

（3）過剩水蒸気存在下では $\mathrm{CH}_{3} \mathrm{CHO}$ に比べ $\mathrm{HCHO}$ 選択性が向 上した。これは, 生成した SMAの固体酸による $\mathrm{C}-\mathrm{C}$ 結合の切 断が $\mathrm{HCHO}$ への応を促進させたものと考えられる。

(4) $\mathrm{MoO}_{2}$ は $\mathrm{C}_{2} \mathrm{H}_{6}$ の活性化の過程で生成し, 水蒸気がその酸化 を抑制していると推定される。 


\section{謝 辞}

本研究は, 日本学術振興会の科学研究費補助金（16201019） の一部を使用して行いました。ここに感謝の意を表します。ラ マン測定に協力いたたいた静岡大学イノベーション共同研究セ ンター友田和一氏に感謝いたします。

\section{References}

1) Hidaka, Y., Sato, K., Hoshikawa, H., Nishimori, T., Takahashi, R., Tanaka, H., Inami, K., Ito, N., Combust. Flame, 120, 245 (2000).

2) Zhao, Z., Yamada, Y., Ueda, A., Sakurai, H., Kobayashi, T., Appl. Catal. A: General, 196, 37 (2000).

3) Zhao, Z., Yamada, Y., Teng, Y., Ueda, A., Nakagawa, K., Kobayashi, T., J. Catal., 190, 215 (2000).

4) Oyama, Ted, S., Somorjai, A. G., J. Phys. Chem., 94, 5022 (1990).

5) Oyama, Ted, S., J. Catal., 128, 210 (1991).

6) Zhao, Z., Kobayashi, T., Appl. Catal. A: General, 207, 139 (2001).

7) Burch, R., Crabb, M. E., Appl. Catal. A: General, 97, 49 (1993).

8) Chao, Z-S., Ruckenstein, E., J. Catal., 222, 17 (2004).

9) Warson, B. R., Ozkan, S. U., J. Catal., 208, 124 (2002).

10) Dinsi, F., Pirone, R., Russo, G., J. Catal., 209, 51 (2002).

11) Beretta, A., Ranzi, E., Forzatti, P., Catal. Today, 64, 103 (2001).
12) Chen, F. N., Oshihara, K., Ueda, W., Catal. Today, 64, 121 (2001).

13) Heracleous, E., Lamonidou, A. A., Appl. Catal. A: General, 269, 123 (2004).

14) Escribano, V. S., Busca, G., Lorenzelli, V., J. Phys. Chem., 94, 8945 (1990).

15) Erdohelyi, A., Solymosi, F., J. Catal., 123, 31 (1990).

16) Aika, K., Lundsord, J. H., J. Phys. Chem., 81, 1393 (1977).

17) Sugino, T., Kido, A., Azuma, N., Ueno, A., Udagawa, Y., J. Catal., 190, 118 (2000).

18) Banares, M. A., Hu, H., Wachs, I. E., J. Catal., 155, 249 (1995).

19) Rocchccioli-Deltcheff, C., Amirouche, M., Herve, G., Fournier, M., Che, M., Tatibouet, J-M., J. Catal., 126, 591 (1990).

20) Rocchccioli-Deltcheff, C., Amirouche, M., Fournier, M., J. Catal., 138, 445 (1992).

21) Mestl, G., Ilkenhans, T., Spielbauer, D., Dieterle, M., Timpe, O., Krohnert, J., Jentoft, F., Knozinger, H., Schlogl, R., Appl. Catal. A: General, 210, 13 (2001).

22) McCarron III, M. E., J. Chem. Soc., Chem. Commun., 336 (1986).

23) Parise, B. J., McCarron III, M. E., Von Dreele, R., Goldstone, A. J., J. Solid State, Chem., 93, 193 (1991).

24) Ramirez, J. I., Cruz, la, M., Mater. Lett., 57, 1034 (2003).

25) Mizushima, T., Fukushima, K., Huong, M. T., Ohkita, H., Kakuta, N., Chem. Lett., 986 (2005).

26) Banares, A. M., Catal. Today, 51, 319 (1999).

27) Sopa, M., Waclaw-Held, A., Grossy, M., Pijanka, J., Npwinska, K., Appl. Catal. A: General, 285, 119 (2005).

要旨

ケイモリブデン酸触媒を用いたエタン酸化反応: 均一・不均一反応下での触媒活性

Tran Mai HuONG, 鈴木 綾乃, 水嶋 生智, 大北 博宣, 角田 範義

豊橋技術科学大学物質工学系, 441-8580 愛知県豊橋市天伯町雲雀ヶ丘1-1

\footnotetext{
シリカ担持ケイモリブデン酸（SMA）触媒を用い,メタン 部分酸化反応に高活性な条件下でエタン酸化反応を試みた。反 応は，無触媒反応（熱反応）が共存する条件で行い，触媒の作 用を調べた。

反応中に水蒸気が存在しない場合や水蒸気量が少ない場合で は, SMA は酸素により $\alpha-\mathrm{MoO}_{3}$ へと変化した。この時, $\mathrm{C}_{2} \mathrm{H}_{6}$ 転化率は向上したが生成物は $\mathrm{C}_{2} \mathrm{H}_{4}$ と $\mathrm{CO}$ であり, $\mathrm{HCHO}$ はほ
}

とんど生成しなかった。水蒸気が過剩になると， $\beta-\mathrm{MoO}_{3}$ と SMA の存在により,HCHOが生成し選択性も向上した。これは， SMA の固体酸性による C-C 結合の切断が部分酸化反応を促進 させたものと考えられる。さらに, $\mathrm{C}_{2} \mathrm{H}_{6}$ と水蒸気が共存する とき $\mathrm{MoO}_{2}$ も生成したことから, 格子酸素がエタンの活性化や 酸化へ関与していると推定される。 